\title{
Radicalisation and Extremism in Eastern Africa: Dynamics and Drivers
}

\section{Patrick Devine}

\section{Introduction}

Understanding the causes and drivers of radicalisation, non-violent extremism and violent extremism is crucial for any organisation involved in improving human security, peacebuilding and reconciliation work.

It should be clear to most observers, particularly scholars and politicians, that Eastern Africa is a strategically important region to recruiters espousing manifestly violent means to achieve social, religious or political goals. It is also clear that it is not only a regional problem, as "violent extremist ideologies are gaining an unprecedented level of traction across the globe, taking root in local communities and controlling territory in a numberof fragile states" (European Commission, 2016, p. 3).

However, this paper seeks to understand the reasons for radicalisation and extremism in Eastern Africa and the ideological dynamics that underpin and structure the way in which they are manifest in that region. It includes an introduction explaining the key terms used, elucidating their conceptual nuances and interconnectedness, followed by an introduction to the underlying causes of radicalisation and extremism in this region and finally, proposals to address and counter these challenges.

Much of the literature on violent extremism focuses on why and how people become drawn into terrorism - the problem often referred to as radicalisation - and how violent extremist groups and networks are organised. Curiously, most of this work or genre is on terrorism as a threat to the West, while the reality is that it is in the countries of Africa and Asia that most of the acts of violent extremism are committed (Kruglanski, et al., 2014).

\section{Definitions and the interconnectedness of concepts}

Firstly, it is important to understand and define the terms used in this discussion and to underline that these concepts are not universally understood in the same way. Essentially, the terms 'fundamentalism,' 'radicalisation,' 'extremism' and 'terrorism' are contested concepts that "have different meanings for different people..." and "their meanings are constantly evolving as they manifest themselves in different ways in different parts of the world" (European Commission, 2016, p. 4). The meanings emerging from such evolutions and manifestations are frequently determined by the level of fusion between religious and ideological worldviews on reality and how society should be structured in the future. 


\section{Radicalisation}

One helpful definition of radicalisation offered by Hann and Fertleman is that "radicalisation is a process by which an individual or group comes to adopt increasingly extreme political, social, or religious ideals and aspirations that reject or undermine contemporary ideas and expressions of freedom of choice. Radicalisation is therefore seen as the process that leads to violence which, in the final analysis, is what distinguishes a terrorist from other extremists" (Hann and Fertleman 2016, p. 106-108). This definition follows a general trend where extremism is understood as not necessarily synonymous with acts of terrorism or violence, in that one can hold extremist views but not act on them in a violent or forceful way. In contrast, 'violent extremism' refers to "the creation of ideologically motivated or justified violence, as well as support for such acts" (European Commission, 2016, p. 5)

Another helpful explanation of the term 'radicalisation' comes from Horgan (2009), who argues it is "the social and psychological process of incrementally experienced commitment to extremist political and religious ideologies" (European Commission, 2016,5). This incremental transition is emphasised in most of the literature whereby when "a decision is made that fear, terror and violence are justified to achieve ideological, political or social change, radicalisation to violent extremism occurs" (European Commission 2016, p. 7). In line with the foregoing, radicalisation is a process that unfolds over time. Generally speaking, in respect to its connectivity with terrorism, it requires the presence of three ingredients:

1. Arousal and activation of the goal of significance;

2. Identification of terrorism and violence as the appropriate means of significance; and

3. Relative devaluation of alternative goals incompatible withterrorism.

These perspectives are in line with psychologists and social psychologists such as Kruglanski et al., (2014), Pape (2005), Bar-Tal (2011) and Schirrmacher (2013), who have addressed issues of radicalisation, fundamentalism, extremism, and terrorism. Without a terrorism-justifying ideology that instructs disaffected individuals as to what must be done to obtain significance, goal activation alone is insufficient for terroristic violent behaviour on their part to occur. Ideology is relevant to radicalisation because it identifies radical activity (such as violence and terrorism) as the means of choice to the goal of personal significance.

\section{Fundamentalism}

The concept of fundamentalism is frequently touched upon in discussions of radicalisation and extremism. For the purpose of this paper, it is discussed under the assumption of international relations being primarily based on a statehood system. The term fundamentalism is used in a variety of ways. What it means or implies, or denies or entails depends on the context in which it is used. Fundamentalism can be characterised as a militant truth claim which derives its claim to power from a non-disputable higher revelation, people, values or ideologies. Frequently it is used in an ideological manner that reflects a 
perception of reality which is distorted by social historical experience. It justifies, urges, uses and propagates non-state or state-based force in order to achieve its goals.

Fundamentalism, historically, has been associated with the domain of religion. Armstrong (2004, p. 9) considers fundamentalism as an "embattled form of spirituality" and "militant piety". However, in the course of time, the term has been extended to designate various forms of behaviour, beliefs, and attitudes which fall outside the field of religion.

In the broadest sense, a religious or world view movement is described as fundamentalist if it calls for reversion to the roots of a certain religion or ideology, which if need be should be asserted with radical and, in part, intolerant means (Ali, 2003). However, religion and the State are not the only motive forces of fundamentalism. All cultural, scientific, political, economic and even artistic systems which assert a claim to be the exclusive bearer of truth, a single solution to existing problems, are fundamentalist. The standpoint of fundamentalism is indisputably about dissent from a particular existing socially acceptable practice, belief and attitude in a wide range of domains. A hard core adherent of fundamentalism in the sphere of religion, is self-convinced that he or she not only knows the truth but also knows that the truth of everyone else is false unless it is the same as theirs.

Fundamentalism is not a constant mind set for the same person at different time periods or a group of people at one-time period. It is a mental attitude that changes in character or degree gradually, or in very slight stages without any clear dividing point between militant and non-militant aspects.

These militant and non-militant states of mind cannot co-exist in the mind of the believer. One or the other tends to predominate, depending on circumstances and environment. The non-militant is inward-directed, and in terms of behaviour it cannot have significant social effects because its substance is self-absorption. The former, militant, is outward-directed and, in terms of behaviour, it has negative social effects in the form of aggression against those whose truth is perceived as false.

Efforts by State actors, faith-based organisations, non-government organisations, and community based organisations that serve to counteract the dynamics of fundamentalism in its militant stream have functional, not dysfunctional, consequences for the non- militant stream of fundamentalism. Both streams of fundamentalism have the potential to serve as drivers of conflict. However, it is imperative to point out, in no uncertain terms, that non-militant fundamentalism is more likely to lead a believer to internalize their aggression. This absorbed form of aggression is likely to take the form of hostile feelings. These must be understood as having potential for physical violence against either people who are seen, through their public or private institutionalised practices, as different. The important thing is that the non-militant fundamentalist is likely to interiorise their hostility in the form of individual self-absorption. This self-absorption, unlike hostile feelings which lead to violence, is socially acceptable because it neither harms other individuals - their raison d'etre - nor adversely affects existing institutional arrangements. Thus, in this connection, it is at once quite reasonable and plausible to state that under conditions of nonmilitancy, fundamentalism gets sublimated into self- absorption and that this process has an important functional in keeping the peace, at least in the sense of an absence of violence. 
The dynamics of fundamentalism at their best may result in a synergy that can be very effective in achieving its goal in the early stages and less productive during latter times, and vice versa depending on the level of opposition encountered. This follows from the fact that fundamentalist behaviour is generally, in the long run, an unsuccessful attempt, since it is always a defence - and alongside that, forcible - against authority or established social values (Almond, Appleby and Sivan, 2003). Fundamentalism is likely to be perceived as an internal challenge, directly and indirectly, to State power; specifically, a challenge to State tolerance.

In general, fundamentalism offers recourse to final truths as the reason for acting against the legitimate use of force by the constitutional State. Fundamentalism has the capacity to be radicalised during its life-span, either at its conception or latter stages, depending on circumstances. The radicalisation may take the form of either non-violent extremism and/or violent extremism ensuing almost concurrently or distant in time. Extremism stemming from radicalised fundamental perspectives is likely to become an object of state surveillance by criterion of tolerance.

Engaging in non-violent extremism is tolerated, not ignored, because it does not harm the cause of the State, due to the fact that its content and expression do not visit disorder in the form of force against the State. Intolerance, the opposite of tolerance, is arguably, non-violent extremism but it is much closer to violent extremism than to tolerance. When non-violent extremism transitions to violent extremism it, in effect, metamorphoses into terrorism, thereby becoming an object of intolerance on the part of the State in the form of eliminations, arrests, detentions and the like. Overall, in terms of process, it is important to point out that the non-militant fundamentalist has potential to be radicalised into a militant fundamentalist who finds expression in non-violent extremism. This process may in turn degenerate into violent extremism operationalised in terrorism.

\section{Tolerance and extremism}

Tolerance is politically constituted and judicially legitimated by the state. The practitioner of tolerance is the government; and the object of tolerance is the social and not the psychological. Tolerance is psychologically exclusive and socially inclusive; it is collective in that it does not accept any absolute liberty for the individual (Bremer, 1974; Mercuse, 1984). Rather, it regards all individual liberty as subject to the overriding authority of the public interest of the State. In ideal terms, tolerance as practiced by the State welcomes every point of view, so to speak, but it demands that addressing and managing conflict internal to the polity be expressed through proper channels and procedures whose order and organisation are structured by established power relations and sanctioned by constitutional prescriptions. It follows, therefore, that although tolerance is basically liberal it has the potential to become intolerant and to take repressive forms if it is threatened by militant fundamentalism or terrorism. The limit of tolerance - the onset of intolerance - is the point in time at which a specific conflict, internal to the polity is deemed by the powers that be or regime in power, as constituting disturbance of the peace or an undermining of established power relations and juridical prescriptions that give order and organisation to the social 
formation. As such, the limitations to tolerance on the part of the State - as defined by judicial institutions and culture - include clear and present danger, signs of manifest violence, threats to national security, and the like.

The parameters of tolerance are that the existing institutional arrangements embody a free society based on a social contract, (Rousseau, 1762, Cole, 2008) and that any improvement, even a change in the social values, comes about in the normal course of events, through development praxis, defined and tested in free and equal discussions engaged in by all the stakeholders, (London 1971; Skinner, 1982). The ideals of tolerance should not be reduced to mere negative peace or the absence of violence. Tolerance is ultimately concerned about achieving positive peace and this is understood as all sides being mutually interested in the security and wellbeing of the other.

In certain Eastern African countries today, tolerance as politically constituted, juridically legitimised and practiced. It is an object of violent extremism expressed in terroristic aggression, seemingly driven by multifaceted fundamentalism.

\section{Terrorism}

In respect to the term terrorism, it is critically important for clarity to examine if there is a difference in categories concerning manifest violent acts associated with the term. For example, there are alternative perspectives and divergences of meaning when the term terrorism on the one hand is applied to the coercive imposition of imperial annexation and/or the religious ideological extremism and, on the other hand, to the collective violent deeds of those who resist such belligerent behaviour in the cause of self- determination, freedom and independence. Surely coercive imperial annexation and enforcement of religious extremism through intolerance of other ideological and religious perspectives are terroristic acts beyond question? However, is the manifest violence used in the cause of defence against the extremism of the agents of imperial manifest violence, structural violence (Gatung, 1969), and violent religious ideologies, to be labelled as terrorism? Surely not, for example, if their actions are guided by the definitions of humanitarian intervention (Holzgrefe and Keohane, 2003) and/or if one upholds the principles of the Just War Theory when in combat, (Johnson, 2008). However, if one violates these principles and engages in the killing and maiming of innocent civilians, then the accusation of terroristic acts is ethically justified.

These three dimensions of terrorism emanating from imperial annexation, religious ideological extremism, and the non-justifiable actions of insurgents resisting the previous two categories, can all be present in the same conflict zone. Furthermore, it is possible that imperial annexation and religious ideological extremism can operate simultaneously and mutually reinforce each other in a terroristic organisation. Indeed, this reinforcement may be so fused that it may be practically impossible to disentangle them. It is also important to bear in mind that conflicts, their dynamics and drivers, are not static; they evolve, and this impacts on the processes of interaction between the three categories. 
Violent extremism is usually considered to be a more inclusive term than terrorism; although, both are broadly synonymous in use (Sedgwick, 2014). The United States Agency for International Development (USAID) considers violent extremism to revolve around procedures of advancing, engaging in, preparing, and supporting violence which is ideologically motivated and justified, for the advancement of social economic and/or political objectives (Glazzard and Zeuthen, 2016).

Violent religious ideological extremism is concerned with eradicating alternative modes of existence and perception in society through terrorism. This purging of society may be operationalised through non-violent, or violent terroristic extremism.

Ultimately, terrorism is the tool of violent extremism used to purge society of tolerance for other modes of existence in respect to worldviews and faith positions. To counter this negative process there is a distinct need, paradoxically, for an intolerance of intolerance. The measuring rod of what defines the substance of human rights becomes of utmost importance if we are to determine the parameters of what is and is not acceptable in terms of tolerance or intolerance. In this regard, the Universal Declaration of Human Rights, among others, is a fundamental historical reference document for evaluating the merits of systems of governance of which democracy is held in highest esteem. It is important to bear in mind that within a governance framework which upholds democracy and respect for human rights, a tolerance towards a multiplicity of fundamental perspectives on issues is expected.

The democratic mode of governance can incorporate various forms of fundamentalism within society. However, when fundamentalism begins to get radicalised towards intolerance, the toxicity of extremism emerges. Overall violent extremism is a result of a general radicalised retrogression, primarily away from a state of tolerance which respects the existence of different fundamental positions. Then, through further negative radicalisation processes, this shift deteriorates into standpoints of non-violent extremism expressing intolerance; involving dimensions of psychological and spiritual warfare $-\mathrm{a}$ form of terrorism in its own right. This stage in the process then becomes the breeding ground for further radicalisation into a phase of manifest violent extremism, set on imposing one model for how society should be structured and operate. This latter phase is operationalised in blood-letting terrorism, set on ridding society of any shred of democracy and respect for fundamental human rights. In reality, this form of extremism is concerned with the use of forceful coercion to purge society of all contrary perspectives and configurations on how society should function.

\section{Causes of radicalisation and extremism in Eastern Africa}

In Eastern Africa, both radicalisation and violent extremism are manifest problems and it is imperative that government bodies, INGOs, NGOs, CBOS, FBOs and civil society in general are actively engaged in countering the conditions and momentum that enable this process to continue. This topic forms the core of the next part of our discussion: what are the underlying causes of the processes of radicalisation and extremism in this region? At this point, it is important to emphasise that none of the following causes are stand-alone factors, nor exclusive of possible other explanatory variables. Each 
depends upon context. Often, radicalisation and extremism occur when there is a combination of a number of these issues affecting an individual's outlook and decision-making mechanisms at one time.

\section{Under-development and poverty}

Poverty and under-development create grievances and desperation that can easily be exploited by extremist groups, especially when these factors are combined with poor governance and the absence of basic service delivery (UNDP, 2016:9). According to the Kenya media, there are many incidences of young men joining extremist groups lured purely by money, assurances of food and shelter, or offered wives by the organisation if they commit to fighting for them (Mukinda, 2016). These recruits may not necessarily share the ideological claims of these groups but the prospects offered are enough to persuade them that fighting for an extremist group offers more opportunity than remaining in poverty and accepting the status quo.

\section{Youth bulge and unemployment}

The population of East Africa is one of the youngest of any region in the world and this trend is projected to continue. This growing youth population is increasingly urbanised, inter-connected by technology and susceptible to messages promoting adventure, purpose and identity. They are susceptible to the aims of the VEOs (Violent Extremist Organisations). According to the Africa Centre for Strategic Studies: "radical organisations understand and prey upon various political realities, socioeconomic factors, and individual characteristics that render youth in East Africa vulnerable to VEO recruitment" (ACSS. p. 7). VEOs understand "young people's quest for meaning and construct worldviews that satisfy youth desires for self-actualisation and fulfilment" (ACSS, p. 11).

In line with the previous factor, unemployment and lack of economic opportunities further increase youth vulnerabilities to radicalisation. The youth population 'bulge' and consequent high unemployment rates have to do with the demographic dividend in terms of interplay between changes in the age structure of the population due to demographic transition and rapid economic growth or industrialisation.

Demographic transition posits that changes in fertility and mortality rates accompanying rapid economic growth or industrialisation involves three phases:

1. a situation in which high birth rates are balanced by high deathrates,

2. an intermediate phase, in which death rates fall but birth rates remain high, and

3. a phase in which death rates fall, leading to a new equilibrium.

In the countries of Eastern Africa, the demographic transition from the second phase to the third phase has been delayed. Consequently, youth dependency rates are high, exposing countries to higher poverty rates, lower labour productivity, high unemployment and the risk of political instability. 


\section{Weak State structures and discriminatory law enforcement}

This region includes a number of vulnerable, weak and failed states and "evidence suggests that weak and failed states - many of which are among the world's poorest countries - are at increased risk of harbouring violent extremists" (Graff, 2010, p. 44). This relates to poor socio-economic service delivery as well as poor law-enforcement. It can also relate to poor government policy or discriminatory behaviours perceived by sections of a population. For example, research conducted in Kenya found that some Muslim youth joined extremist groups as a reaction to the Kenyan government's policy of collective punishment or assassination of their religious leaders as part of counter- terrorism initiatives (Botha, 2014).

Arguably it is justifiable to maintain that, in any State, a government basing its anti- terror strategies based on mass arrests, selective racial, ethnic and religion profiling, may find this to be counterproductive because it is likely to drive individuals to extremism. On the other hand, taking the case of Kenya, whose defence forces are active in Somalia dealing with the Al-Shabaab terrorist threat, and bearing in mind that a large Somali population lives within Kenya's borders, one would be somewhat surprised if there was not some selective monitoring of the activities of Somali youth.

Another important reality, in many areas of Eastern Africa, is that the State is not robustly present. This is most evident in the dire lack of government structures and institutions that are essential if people are to meet their basic human and ontological needs (Maslow, 1970; Burton 1997) and for the actualisation of their potential (Galtung, 1969, 1971). Such a situation leaves power vacuums and high levels of public dissatisfaction and increases the likelihood that a disgruntled population will embrace other leadership structures, particular interest groups or ambitious individuals, who have an opportunity to offer alternative narratives. From these platforms other factions evolve to assert themselves physically as sub-state actors, implementing their own interpretations of what constitutes fundamental human rights, applying their own versions of law and order while justifying all forms of manifest and structural violence to achieve their ends.

In respect to the Charter of the United Nations (1945) and the Universal Declaration of Human Right (1948), and amendments adopted, the expansion of sub-state actors demonstrates an alarming threat to the accepted governance foundations of State legitimacy.

\section{Religion-based justification of violence}

When religion becomes energised by increasing quantitative institutional membership rather than qualitative spiritual transformation, the potential for it to become a destructive factor in conflict generation escalates (Devine, 2011, McMullen, 2017). This is the experiential and theoretical standpoint that informs the author in terms of the link between religion, on the one hand, and the dynamics and drivers of radicalisation and extremism on the other. In Eastern Africa, evidence for this can be drawn from a multiplicity of examples ranging from attacks on US Embassies in Tanzania and Kenya, businesses in Uganda, Westgate Mall in Nairobi, the massacre of students at Garissa University in eastern Kenya, and 
most notably, in the ongoing manifest conflict in Somalia. Within this environment, the propagation of religions as institutions becomes the primary focus rather than their core spiritual message, with respect to tolerance, peace, truth, justice and mercy. This context often breeds a form of religious ideological extremism which predominantly fosters exclusivist, violent tendencies, violating fundamental human rights. In this respect, religious ideological extremism can be the foundation and driver of radicalisation and extremism underpinning the imperial annexation of territory, solely bent on creating theocracies which are intolerant of all other forms of religious belief or freedoms. Essentially, this points to how religion can potentially be manipulated in the interest of either promoting negative values and extremist positions, or the opposite.

Moreover, all religions depend on the motivations and interpretations of their adherents and are therefore susceptible to misuse of their pedestals. It should be noted, that in the debate on religion causing extremism, some research, (Crone, 2016), suggests that theology remains a prevalent scapegoat for extremism and that most perpetrators of terror already have violent histories and criminal records before they eventually endorse terroristic acts. However, it is clear that religious networks, rhetoric and places of worship have been and are abused for radicalisation and extremist aims. This is not a new phenomenon confined to any one religion (Omoka, 1980). The religionisation of politics and the politicisation of religion (Devine, 2011) have severe negative implications on the process which has seen tolerance deteriorate into intolerance, leading to more radicalised fundamentalism which, in turn, becomes a basis for further degeneration into extremism and manifest extremism, whereby society is to be purged of any contradictory position.

When the purity of the 'Divine' values and principles in a religion's message are distorted, subverted or forfeited in the interest of a religion's institutional earthly socio- political-economic objectives, the authentic beliefs and corresponding behaviour become toxic. The idealism and purity of the 'Divine' message is subjected to socio-political realism objectives of worldly security and interests. Within the context of clashes, be they ideological, religious or civilizations (Huntington, 1993), conflict will almost inevitably emerge in forms of structural and/or manifest violence, to achieve these ends. It is within this process dynamic that the tolerance of alternative faiths, institutions, even a person's right to be born or exist, becomes unacceptable. This is unquestionably evident in the domains of non-violent extremism and manifest violent extremism.

Religion's role in healing or fuelling conflict, either directly or indirectly, or, as the case may be, deliberately or unintentionally, ultimately has to critique its own institutional politicisation. This is where its institutionalism faces the real danger of usurping the focal point of religion and positioning God as an additive to justify the institution. When the institution becomes the god-sacred epicentre then violence will seek justificatory arguments defending cases ranging from those of individual abuse to suicide bombing and mass killing. All the major religions of the world have to take stock of the internal dangers in their structures and governance, to avoid their 'Divine' or 'sacred' message becoming radicalised by institutional concerns leading to non-violent extremism and further evolving towards the justification and actuality of manifest violent extremism operationalised through terrorism. 


\section{Identity crises}

Some argue that it is not religion or ideology that drives propels people toward joining extremism groups; rather the propulsion is motivated by a psychological need for significance which extremist groups provide in terms of purpose, self-worth, certainty and belonging to a cause (Lyons-Padilla, et al., 2015, p. 1-12). Some analysts point to a "crisis of national identity" as a cause of radicalisation in this region, whereby people are more easily persuaded to buy into radical, transnational narratives or, on the other hand, it can also manifest as radicalisation along "ethnic, clan or communal lines when a strong sense of nation is absent from the national consciousness" (ACSS, 2012, p. 13). This psychological desire to belong and to make one's mark in the world is a recruitment tool used by extremist organisations in areas where socioeconomic and political opportunities are minimal and the option to join a global or regional cause of seeming significance can be very appealing.

\section{Media and globalisation}

Networking in Eastern Africa is a growing social practice, if not a cultural priority, and with the growth of internet access and other media, East Africans are increasingly connected via information and communication technology to each other and the global marketplace of transformative ideas, be they positive or negative (ACESS, 2012). This ever-expanding access to information and ideas naturally carries with it pros and cons. Particularly on the internet, the global issue of 'fake news,' biased perspectives lacking objectivity and inaccurate reporting, mislead and radicalise vulnerable groups from positions of tolerance to various intensities of intolerance. Extremist groups are well known for their use of social media, radio, television and other media to spread propaganda and aid their recruitment processes.

\section{Easy access to weapons and sources of funding}

This factor again relates to environments where the State structures are weak and a power vacuum exists, leaving large areas uncensored and not subject to regulations concerning weaponry and movement of money. Furthermore, the availability of funds from established and wealthy extremist groups such as Al-Qaeda and ISIS, makes it possible for people with unmet financial needs to be recruited into such extremist groups (UNDP, 2016).

Fundamentally, community resilience to extremist ideologies needs to be built in every sphere of the social fabric of this region. The responsibility for easy access to weapons and sources of funding also has to be owned by certain developed world countries and their governance structures. In this respect they are implicated in all stages of the retrogression from tolerance via fundamentalism, radicalisation, and non-violent extremism to manifest violent extremism, operationalised in terrorism. 


\section{Proposals for countering the causes of extremism}

As the previous section indicates, the underlying causes of radicalisation and extremism are complex and varied. Therefore, any intervention to counter these factors needs to take this perspective into account and to offer a multi-faceted, yet unified, approach to tackling the conditions that allow radicalisation and extremism to intensify. Furthermore, interventions need to be created for contexts in which extremism has already taken root. Moreover, an alternative narrative and presentation of opportunities are necessary to prevent this radicalisation transitioning to intentional violence. In this vein, a conflict transformation-development approach is not only critical but imperative if the underlying causes are to be strategically addressed and resolved. In doing this, it is essential to draw on the theory and practice of qualified and experienced peace and development practitioners (for example Lederach et., al, 2007; Lederach, 2010; Ayangafac and Cilliers, 2011; UNDP, 2016; McHugh, 2017), among others.

It is impossible to overstate the importance of empowering communities in conflict and marginalised zones, who are easily impacted by radicalisation and extremism. This can best be done by:

- equipping them with both the appropriate practical analytical skills enabling them to see what is causing conflict and

- teaching applicable peacebuilding techniques which they can use.

In tandem with this, if more people have access to socio-economic amenities, they are generally less susceptible to messages promoting violence and turbulence as a means to a certain end, because they have investments and stability that they wish to protect.

Besides, the sense of purpose that an individual gain when in secure employment, with potential for personal advancement, often counters the lack of identity experienced by the jobless or young people looking for an opportunity of self-advancement and/or sense of significance.

Governmental and security sector reform provide another approach and this is necessary if we are to adequately address the problems at the core of this discussion. The apparatus used by a repressive State, in the form of the police and army, are insufficient to deal with the underlying causes of radicalisation and extremism. To attend to these causes there is need for greater use of the ideological State apparatuses (see Althuser, 1971), mobilised through educational institutions, religious organisations, and the media. The weak state structures and evidence of discriminatory law-enforcement in some parts of the region need to be challenged and reformed. This should also include stricter legislation concerning gun-control and the movement of weapons in each State andacross their borders.

Advocacy and communication are important tools in tackling radicalisation and extremism. With increased access to social media and the global problem of misinformation, there needs to be a concerted effort to promote and disseminate an objective factual narrative. This is essential in order to counter those that encourage division, exclusion or demonization of the 'other,' to the point where violence is somehow justified and pursued. The lack of objectivity in reporting, be it through 'fake news', mendacious, and/or non-lying half-truth news, is a crucial issue for journalism to address if the devastating processes that lead to terrorism are to be countered. More than ever, the qualifications and 
standards required from journalists need to be assessed against the benchmark of credibility.

Religious institutions have a vocational role and responsibility to play, first and foremost, in fostering the values of truth, justice and mercy over deception and division. Religious leaders and their followers should continuously be engaged in promoting tolerance, bearing in mind that their spheres of influence and opportunities to persuade others are often, for example, psycho-spiritually more in-depth and further-reaching than governmental institutions. Essentially, there is often a 'war of ideas' at the heart of conflict and violence. There is a need for religious leaders to have greater exposure to and proficiency in the areas of peace studies, development, comparative religion and international relations.

Youth engagement is vital. Young people are full of potential and yet vulnerable to peer pressure. If they perceive only one route, they will most likely follow it. It is imperative that schools, universities, youth clubs and sports clubs engage with vulnerable groups and offering them alternative opportunities and perspectives to that which offers a radical or violent path. Radicalisation reflects increased commitment to the ideological quest for significance and to the violent means of its pursuit, coupled with reduced commitment to alternative, incompatible pursuits. A radicalised youth has fallen under the influence of social networks of which he or she has become a member. In this connection, deradicalisation capable of countering the cause of extremism constitutes a weakening of such influence and an increased likelihood of a would-be adherent falling outside its sphere. Thus, achieving de-radicalisation involves:

1. Vocational education training for the purpose of re-integrating the disaffected and detained into society, thereby enabling them to regain a sense of personal significance. The psychological research-based evidence for this point is that the seeming heterogeneity of motives underlying engagement in terrorism boils down to a major underlying motivation, namely the quest for personal significance.

2. Involving detainee families in the rehabilitation process as a way of activating non-ideological concerns incompatible with violent sacrifice for acause.

3. Separating the leaders from followers, thus breaking the collective group reality dominated by the extremist.

4. De-radicalisation, having as one of its dimensions a set of constituted spiritual activities whose object is the individual.

5. Psychological transformation addressing issues of tolerance, revenge and intolerance. Revenge is the desire to reciprocate harm against those whohave caused harm to oneself or one's group, thus redeeming one's lost significance (Dollard, 1939; Berkowitz, 1969; London, 1971; Collier and Hoeffler, 2004). 
Revenge levels the playing field and restores the balance of power by dealing a humiliating blow to one's enemy, thus redeeming one's lost significance. De- radicalisation should first and foremost establish whether the extremism fundamentally stems from matters social, economic, political, religious or cultural; or whether it is a manifestation of revenge, statistically independent of these other causes, in all its forms and expressions.

\section{Conclusion}

To counter radicalisation and extremism, it is necessary to recognise that it is the responsibility and task of everyone in every sector of society. There are no quick-fixes or easy solutions. A multidimensional approach is necessary, engaging levels and strata of society from the grassroots of civil society to government and inter-governmental structures.

A realistic proposed solution for the future of nation-states and their societies will not be that all people abandon the truth claim of their faith, their ethics, or their political convictions - especially since one could only compel that externally with force. Rather, at a minimum, it has to involve learning how to accomplish peaceful co-existence among people of differing beliefs, convictions and ideologies. Moreover, this peaceful objective is not just about tolerating the qualitative and quantitative dynamics of behavioural differences, which may only be regarded as mere negative peace. It concerns all sides rising to the mission of adeptly exploring the others' perceptions and positions, with a vision of attaining greater mutual enlightenment, advancing the peace and development praxis of all humanity. 


\section{References}

Africa Center for Strategic Studies (ACSS). (2012). Preventing Youth Radicalization in East Africa.

Retrieved from: http://africacenter.org/wp- content/uploads/2016/01/Preventing-Youth -

$\underline{\text { Radicalization-in-East-Africa-Program-Summary-ACSS.pdf }}$

Ali, T. (2003). The clash of fundamentalisms: Crusades, jihads and modernity. Brooklyn, New York: Verso.

Almond, G. A., Appleby, R. S., \& Sivan, E. (2003). Strong religion: The rise of fundamentalisms around the world.

University of Chicago Press.

Althusser, L. (1971). Ideology and ideological State apparatuses (Notes towards an investigation). Lenin and Philosophy and other Essays.(Ss. 127-186).

Armstrong, K. (2004). Fundamentalism and the secular society. International Journal, 59(4), 875-877.

Ayangafac, C. and Cilliers, J. (2011). African Solutions to African Problems. Assessing the Capacity of

African Peace and Security Architecture. In Crocker, C. A., Hampson,

F. O. \& Aall, P. R., Rewiring Regional Security in a Fragmented World.

Washington, DC: United States Institute of Peace.

Bar -Tal, D. (2011) Intergroup conflicts and their resolutions: Social Psychological Perspective. New

York, NY: Psychology Press

Berkowitz, L. (1969). The Frustration-Aggression Hypothesis Revisited. In Berokowitz (Ed.), Roots of Aggression.

New York: Atherton Press.

Botha, A. (2014). Political Socialization and Terrorist Radicalization Among Individuals Who Joined al-

Shabaab in Kenya. Studies in Conflict \& Terrorism, 37(11), 895-919.

Bremer, C. (1974). An Elementary Textbook of Psychoanalysis. New York: Doubleday.

Burton, J. (1997). Violence Experienced: The Sources of Conflict Violence, and Crime and their Prevention. New

York: Manchester University Press

Cole, .D.H. (2008). Translation of the Social Contract. New York: Cosimo Classics.

Collier, P., \& Hoeffler, A. (2004). Greed and Grievance in Civil War. Oxford Economic Papers 56 (4), 563 -

595.

Crone, M. (2016). Radicalization revisited: Violence, politics and the skills of the body. International Affairs, 92(3), 587-604.

Devine, P. (2011). A critical analysis of the role of religion in fuelling or healing conflict. Tangaza Joumal of Theology Mission, (1), 52-69.

Dollard, J. (1939). Frustration and Aggression. New Haven: Yale University Press. European Commission.

(2015). Strive for Development: Strengthening Resilience to Violent Extremism.

Retrieved from, https://ec.europa.eu/europeaid/sites/devco/files/strive-

brochure-20150617 en.pdf

Galtung, J. (1969). Violence, Peace and Peace Research. Journal of Peace Research, 3, 167-191.

Galtung, J. (1971). A Structural Theory of Imperialism. Journal of Peace Research, 8(2), 
$81-117$.

Galtung, J. (1985). Twenty-five years of peace research: Ten challenges and some responses. Journal of Peace Research, 22(2), 141-158.

Glazzard, A., and Zeuthen, M. (2016). Violent Extremism. GSDRC Professional Development Reading Pack (34). Birmingham: University of Birmingham.

Graff, C. (2010). Poverty, Development and Violent Extremism in Weak States. Washington D.C: Brookings Institute.

Hann, G., and Fertleman, C. (Eds.). (2016). The child protection practice manual: training practitioners how to safeguard children. Oxford: Oxford University Press.

Holzgrefe, J. L., and Keohane, R. O. (Eds.). (2003). Humanitarian intervention: Ethical, legal and political dilemmas. Cambridge: Cambridge University Press.

Horgan, J. (2009). Walking away from terrorism: Accounts of disengagement from radical and extremist movements.

Routledge.

Huntington, S. P. (1993). The Clash of Civilizations? The Debate: A foreign Affairs Reader. New York: Council on Foreign Relations.

Johnson, J. T. (2008). The idea of defense in historical and contemporary thinking about just war. Journal of Religious Etbics, 36(4), 543-556.

Kruglanski, A. W., Gelfand, M. J., Bélanger, J. J., Sheveland, A., Hetiarachchi, M., and Gunaratna, R. (2014). The psychology of radicalization and deradicalization: How significance quest impacts violent extremism. Political Psychology, 35(S1), 69-93.

Lederach, J.P., Neufeldt, R., \& Culbertson, H. (2007). Reflective peacebuilding: A planning, monitoring, and learning toolkit. Notre Dame: Kroc Institute of International Studies, University of Notre Dame.

Lederach, J. P., (2010). Peacebuilding and Catholicism, in Peacebuilding: Affinities, Convergences, Possibilities, In R. J. Schrieter, R. Scott Appleby, Gerard F. Powers, (Eds.), Peacebuilding Catholic Theology, Ethics, and Praxis. New York: Orbis Books.

London, P. (1971). Behaviour Control. New York: Harper \& Row.

Lyons-Padilla, S., Gelfand, M. J., Mirahmadi, H., Farooq, M., \& VanEgmond, M. (2015).

Belonging nowhere: Marginalization \& radicalization risk among Muslim immigrants. Behavioural Science \& Policy, 1(2), 1-12.

Maslow, A, H. (1970). Motivation and Personality, (2 ${ }^{\text {nd }}$ Ed). New York: Harper and Row.

McHugh, J. (2017). http://www.shalomconflictcenter.org/?cause=conflict-resolution-in- kenya

McMullen, S. (2017). http://www.shalomconflictcenter.org/an-interview-with-fr-patrick- devine-inwashington/

Mercuse, H. (1984). One-Dimensional Man. London: Routledge and Kegan Paul.

Mukinda, F. (2016, February 11). Kenya: Al-Shabaab preys on poor youth with promisesof cars and wives. Daily Nation, retrieved from http://allafrica.com/stories/201602120171.html 
Omoka, W.K. 1980, Strategies and tactics of inauguration of African underdevelopment: the case of Christian missionization violence in East Africa. Ufahamu, Vol., 9.

Paper, R.A.(2005) Dying to win: The Strategic logic of terrorism. New York, NY: Random House Rousseau, J. J. (1762). The Social Contract. Amsterdam: Chez Marc-Michel Rey.

Schirrmacher, T. (2013). Fundamentalism: When Religion Becomes Dangerous. Hamburg, Germany: World Evangelical Alliance.

Sedgwick, M. (2014). Muhammad Abduh. London: One world Publications. Skinner, B.F. (1982). Beyond Freedom and Dignity. New York: Penguin Books.

United Nations Development Programme (UNDP). (2015). (Third Expert Consultation, Addis Ababa,) http://www.undp.org/content/dam/undp/library/Democratic\%20Governance/Local\%20G overnance/UNDP-RBA-Preventing-Extremism-2015.pdf

United Nations Development Programme (UNDP). (2016). Preventing and Responding to

Violent Extremism in Africa: A Development Approach (Addis Abbas). Retrieved from:

http://www.sl.undp.org/content/dam/sierraleone/docs/annualreports/Rep ort $\% 20$ on $\% 20$ Violent $\% 20$ Extremism18Nov2015.pdf

United Nations (UN). (1945). The Charter of the United Nations. New York: United Nations Department of Public Information.

United Nations (UN). (1948). Universal Declaration of Human Rights. New York: United Nations

Department of Public Information.

Fr Patrick Devine PhD is the founder of the Shalom Center for Conflict Resolution and Reconciliation (SCCRR), an inter-religious organization based in Nairobi, Kenya. The Center pioneers conflict resolution and development work in strife-ridden areas of Eastern Africa.

At the center, qualified staff conduct empirical research on the root causes of inter- ethnic conflicts. They also engage in a number of peace-orientated projects, organise workshops to facilitate resolution and reconciliation between factions, train local peace- builders and develop inter-ethnic schools powered by solar energy.

The mission of the center is to work towards a society free of physical violence and unjust social structures in Africa. Fr Devine was the Winner of the 2013 International Caring Award for his contribution to peace and development in the IGAD region. He is a lecturer on conflict resolution and reconciliation, Tangaza University College, Nairobi, Kenya. 